\title{
Systematic Review of Incidence Studies of Pneumonia in Persons with Spinal Cord Injury
}

\author{
Anja Maria Raab ${ }^{1,2}{ }^{*}$, Gabi Mueller ${ }^{1}$, Simone Elsig ${ }^{3}$, Simon C. Gandevia ${ }^{4,5}$, Marcel Zwahlen ${ }^{6}(\mathbb{D}$, \\ Maria T. E. Hopman ${ }^{7}$ and Roger Hilfiker ${ }^{3}$ (D)
}

check for updates

Citation: Raab, A.M.; Mueller, G.; Elsig, S.; Gandevia, S.C.; Zwahlen, M.; Hopman, M.T.E.; Hilfiker, R. Systematic Review of Incidence Studies of Pneumonia in Persons with Spinal Cord Injury. J. Clin. Med. 2022, 11, 211. https://doi.org/ $10.3390 / j \mathrm{~cm} 11010211$

Academic Editor: Satoru Ebihara

Received: 12 November 2021

Accepted: 26 December 2021

Published: 31 December 2021

Publisher's Note: MDPI stays neutral with regard to jurisdictional claims in published maps and institutional affiliations.

Copyright: (C) 2021 by the authors. Licensee MDPI, Basel, Switzerland. This article is an open access article distributed under the terms and conditions of the Creative Commons Attribution (CC BY) license (https:// creativecommons.org/licenses/by/ $4.0 /)$.
Clinical Trial Unit, Swiss Paraplegic Centre, 6207 Nottwil, Switzerland; gabi.mueller@paraplegia.ch Department of Health Professions, Bern University of Applied Sciences, 3008 Bern, Switzerland

3 School of Health Sciences Valais, Physiotherapy, University of Applied Sciences and Arts Western Switzer Land Valais, 1950 Sion, Switzerland; simone.elsig@hevs.ch (S.E.); roger.hilfiker@hevs.ch (R.H.)

4 Neuroscience Research Australia, Randwick 2031, Australia; s.gandevia@neura.edu.au

5 School of Medical Sciences, University of New South Wales, Sydney 2052, Australia

6 Institute of Social and Preventive Medicine, University of Bern, 3012 Bern, Switzerland; marcel.zwahlen@ispm.unibe.ch

7 Department of Physiology, Radboud University Nijmegen, 6525 Nijmegen, The Netherlands; maria.hopman@radboudumc.nl

* Correspondence: anja.raab@bfh.ch

\begin{abstract}
Pneumonia continues to complicate the course of spinal cord injury (SCI). Currently, clinicians and policy-makers are faced with only limited numbers of pneumonia incidence in the literature. A systematic review of the literature was undertaken to provide an objective synthesis of the evidence about the incidence of pneumonia in persons with SCI. Incidence was calculated per 100 person-days, and meta-regression was used to evaluate the influence of the clinical setting, the level of injury, the use of mechanical ventilation, the presence of tracheostomy, and dysphagia. For the meta-regression we included 19 studies. The incidence ranged from 0.03 to 7.21 patients with pneumonia per 100 days. The main finding of this review is that we found large heterogeneity in the reporting of the incidence, and we therefore should be cautious with interpreting the results. In the multivariable meta-regression, the incidence rate ratios showed very wide confidence intervals, which does not allow a clear conclusion concerning the risk of pneumonia in the different stages after a SCI. Large longitudinal studies with a standardized reporting on risk factors, pneumonia, and detailed time under observation are needed. Nevertheless, this review showed that pneumonia is still a clinically relevant complication and pneumonia prevention should focus on the ICU setting and patients with complete tetraplegia.
\end{abstract}

Keywords: pneumonia; spinal cord injury; systematic review; incidence

\section{Introduction}

Pneumonia continues to complicate the course of spinal cord injury (SCI). Currently, clinicians and policy-makers are faced with only limited numbers of pneumonia incidence in the literature. Respiratory complications are one of the main comorbidities after SCI, especially among persons with cervical and high thoracic injury [1]. The underlying problem is paralysis of the respiratory muscles, which leads to poor mobilization of secretion, bacterial accumulation in the secretion, and resultant respiratory infections [1-3]. The higher the level of SCI, the greater is the risk of respiratory complications [2]. About 30\% of all deaths after an SCI are due to respiratory causes, with pneumonia as the most common respiratory cause [4].

Pneumonia is defined as inflammation of the lung tissue and is usually caused by infection [5,6]. The United States Centers for Disease Control and Prevention provide an overview of causes of pneumonia [7]. Pneumonia can be caused by viruses, bacteria, and 
fungi. Common causes of viral pneumonia are influenza viruses, respiratory syncytial virus, and SARS-CoV-2. A common cause of bacterial pneumonia is Streptococcus [8,9]. However, clinicians are not always able to find out which pathogen caused pneumonia. Generally, the bacteria and viruses that most commonly cause pneumonia in the community are different from those in healthcare settings [7]. Diagnosis can be made by radiographic signs of parenchymal disease [6] or clinical signs such as fever, inflammatory markers or purulent tracheobronchial secretions.

Pneumonia profoundly impacts the length of hospital stay and the neurological outcome in persons with SCI [10]. Many persons with SCI, who survive acute hospitalization, die within 6.2 years after discharge [11], mainly as a result of cardiovascular (13-37\%) and pulmonary diseases (9-30\%) [11-13]. In patients with community-acquired pneumonia, the case fatality rate for pneumonia ( $7.9 \%$ within 60 days) is greater in persons with SCI compared to the general population, and hospitalizations are more frequent with increasing age, tetraplegia, and the occurrence of comorbidities [14]. Male gender, motor complete injury, presence of chest trauma and the timing of intubation are key predictors for pneumonia in SCI [10].

The risk of pneumonia is the sum of different factors such as level of injury, the clinical setting, the use of mechanical ventilation, the presence of tracheostomy, and dysphagia. The higher the level of spinal-cord damage, the more severe are the respiratory impairment [15] and the risk of pneumonia. Respiratory dysfunction in SCI can be considered in 2 phases: (1) the initial phase immediately following the injury and the year thereafter, and (2) the chronic phase during the rest of the life of the affected individual [16]. Early after an injury, a reduction in lung compliance occurs, with reduced lung volumes and changes in the mechanical properties of the lung [16]. Brown et al. described an improvement of respiratory function with time depending on the level and completeness of the injury, the extent of the spontaneous recovery, and other factors [16]. Thus, the time post injury and the setting play an important role in the development of pneumonia. Patients affected by pneumonia can be admitted to ICUs independently by the setting where the infection has been acquired [17]. However, frequently pneumonia can develop in patients already in an ICU, especially in those requiring mechanical ventilation [17].

In persons with severe paralysis, the risk of dysphagia is increased, particularly in the first weeks after injury [18]. Mechanical ventilation and prolonged tracheostomy further increase the risk of pneumonia $[19,20]$. Shem et al. reported that $75 \%$ of spinal cord injured patients with dysphagia developed pneumonia compared to $29 \%$ without dysphagia [19]. Martin et al. showed that pneumonia is significantly associated with the need for a tracheostomy in $67 \%$ of patients with SCI [21].

A formal incidence of pneumonia in persons with SCI is still missing and, to our knowledge, this is the first systematic review of the incidence of pneumonia in the SCI population. Incidence of a disease indicates the number of new cases within a time period in a population. Systematic reviews of prevalence and incidence data are becoming increasingly important as decision-makers realize their usefulness in informing policy and practice [22]. Accurate estimates of the true incidence of pneumonia are also of value in improving the understanding and awareness in an SCI population and in planning diagnostic and intervention services. We hypothesized that the risk of pneumonia may be influenced by various factors such as the clinical setting, the level of injury, the use of mechanical ventilation, the presence of a tracheostomy, and the presence of dysphagia. Therefore, a systematic review of the literature was undertaken to provide an objective synthesis of the evidence about the incidence of pneumonia in persons with SCI using five covariates: clinical setting, the level of injury, use of mechanical ventilation, presence of tracheostomy, and dysphagia.

\section{Materials and Methods}

We conducted a systematic review and meta-regression of incidence studies of the incidence of pneumonia in SCI. The review was guided by the recommendations provided 
for Meta-analysis of Observational Studies in Epidemiology (MOOSE) and guidelines for undertaking systematic reviews of incidence and prevalence studies $[23,24]$. The review was registered with the International Prospective Register of Systematic Reviews (PROSPERO 2019 CRD42019129048).

\subsection{Types of Studies}

We considered all types of studies for inclusion, except case studies.

\subsection{Literature Searches}

A variety of sources were used to find relevant publications, including PubMed, EMBASE, MEDLINE (Ovid) and the Cochrane Central Register of Controlled Trials (CENTRAL) databases. Search terms and the combination of exploded Medical Subject Heading/Emtree terms using "or" and "and" per database specification are provided in Supplementary File S1. One review author (AMR) designed this search strategy in collaboration with an experienced health librarian. A systematic and comprehensive search was scheduled on 20 March 2019 with a final update on 12 May 2020. We also searched the reference lists of relevant papers and literature reviews by hand. We contacted study authors to acquire information that was not included in their articles. Additionally, we contacted experts in the field to find all publications that matched our inclusion criteria. Initially we applied no date, language or publication restrictions. The search strategy for the six databases is provided in Supplementary File S1. However, three papers in Chinese, Danish, and Icelandic could not be translated and they were not included in the analysis. No other studies required translation into English. Papers with low incidence may be under-represented in our final list of publications.

\section{Eligibility Criteria}

We included studies involving male and female patients with a primary diagnosis of traumatic or non-traumatic SCI, American Spinal Injury Association Impairment Scale (AIS) A-D, right and left motor level between C1-L5, both acute and chronic. The participants were 18 years of age and over. In those studies with missing information about the AIS grade, we contacted the authors of the study. For those who gave no answer we used the following definition: "complete" SCI indicates AIS A in which no motor or sensory function is preserved, and "incomplete" SCI indicates an AIS B,C,D in which sensory but no or partial motor function is preserved [25]. In the included studies, only the term "pneumonia" was used, and the causes and types of pneumonia were not specifically defined. Therefore, analysis among different types of pneumonia was not possible.

Studies on patients with progressive neurological diseases such as multiple sclerosis, poliomyelitis or amyotrophic lateral sclerosis were excluded as well as studies on patients with mental disorders, patients taking bronchodilators or any other medication that influences respiration at the time of assessment. We also did not include studies that investigated pneumonia caused by the recently discovered coronavirus with the outbreak in China in December 2019 and the ensuing pandemic.

Full-text, peer-reviewed studies were required to report data on incidence of pneumonia in persons with SCI. Studies could be conducted in the hospital or community setting.

\subsection{Study Records}

The search results were collated in an EndNote X8 database (Clarivate Analytics, Philadelphia, PA, USA). Duplicates were removed before search results were analyzed. Two review authors (A.M.R., S.E.) independently assessed the titles and abstracts to identify potentially relevant articles by using the Covidence systematic review software (Veritas Health Innovation, Melbourne, Australia). After initial screening, the two review authors independently assessed the full texts of the retrieved articles for compliance with the eligibility criteria. Disagreement was resolved by discussion. In cases when no decision 
could be made by consensus, a third author (G.M.) was consulted for discussion until agreement could be reached. A PRISMA flow chart of the study selection procedure was created (Figure 1).

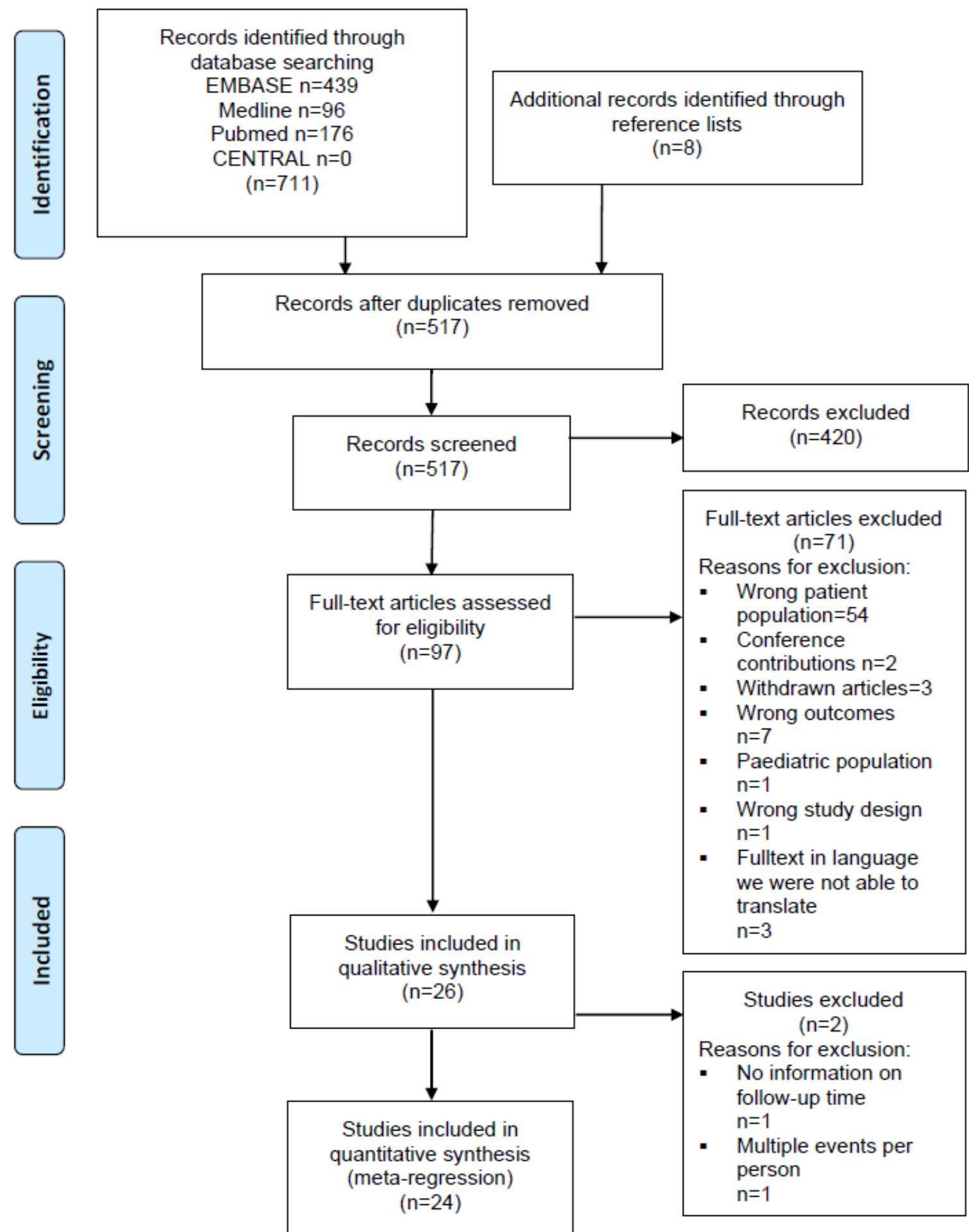

Figure 1. PRISMA flow diagram. Systematic review of incidence studies of pneumonia in persons with spinal cord injury. 


\subsection{Data Extraction}

Methods and population characteristics reported across studies were selected for data extraction. One review author (A.M.R.) extracted and coded data from included studies by using a predefined form. A second review author (R.H.) checked the extracted data. The second review author consulted the first one in cases where there was disagreement to find a consensus. The following items were extracted: year of publication, country, design of study, sample size, clinical setting, age, sex, AIS grade, level of injury, length of hospital stay, use of mechanical ventilation, length of observation, and the incidence of pneumonia.

\subsection{Data Processing}

We calculated incidence rates per 100 person-days based on the number of events divided by the total exposure time in days. Because most of the studies only reported overall follow-up time and not the exact time at risk to develop pneumonia, we estimated the time at risk by taking the mean follow-up time in days for patients without pneumonia and by taking half of the mean follow-up time in days for the patients with pneumonia to adjust for the reduced time at risk in persons with a pneumonia (i.e., the person stops being at risk when diagnosed with a pneumonia) [26]. The time at risk was then multiplied by the number of participants in the study. We only considered cases with pneumonia and not episodes of pneumonia, i.e., each person was considered only once in the calculations. In a sensitivity analysis, we calculated a minimal follow-up time by using 0 days for the cases and a maximal follow-up time by using the full follow-up time for all patients.

\subsection{Risk-of-Bias Assessment}

Risks of bias were assessed for all included studies using a "Quality assessment checklist for prevalence studies" developed by Hoy et al. [27]. The tool consists of 10 questions, and each question can be answered as "yes", defined as low risk of bias or "no", defined as high risk of bias. The quality assessment questions addressed external validity (items 1-4) and internal validity (items 5-10) (Supplementary File S2). We selected the five most important items for the aims of our study (items 2, 4, 6, 7, 10). We decided for a conservative procedure that the worst item out of these five items was decisive for the rating of the whole study. Uncertainties in rating of the risk of bias were resolved by discussion with two further authors (R.H., G.M.). The full risk-of-bias assessment is shown in Supplementary File S3. We planned to perform sensitivity analyses comparing results from studies with a high risk of bias compared to studies with low risk of bias within the subgroups.

\subsection{Data Synthesis}

The incidence rates were used to calculate pooled incidence rates per subgroup (i.e., for each combination of the study characteristics) with a random-effects meta-analysis and were used to perform a meta-regression to provide the incidence-rate ratios for the independent variables: Setting, Level of Injury, Ventilation, Tracheostomy, and Dysphagia [28]. Five categorical variables were used to create the subgroups and as independent variables in the univariable and multivariable regression models: Setting (Acute, ICU, Rehabilitation, Post-Rehabilitation, Long-Term Ventilated, and Mixed), Level of Injury (studies with only persons with paraplegia, studies with only persons with tetraplegia, studies where more than $50 \%$ but less than $100 \%$ of the persons had paraplegia, studies where more than $50 \%$ but less than $100 \%$ of the persons had tetraplegia, and "mixed" for studies where the proportion of persons with paraplegia or tetraplegia was not reported), Ventilation (Not Ventilated or No Information, Ventilated, and Mixed), Tracheostomy (No, Yes, Mixed), Dysphagia (Not Mentioned, No, Yes). The categorical variable dysphagia was not entered in the multivariable meta-regression because of the low number $(n=2)$ of included studies with information on dysphagia.

Settings were divided into ICU, acute phase, rehabilitation phase, post-rehabilitation phase and mixed setting, in which the first three settings are linked to hospital-acquired pneumonia and post-rehabilitation is linked to community-acquired pneumonia. Mechan- 
ical ventilation means ventilation through a tracheostomy or an endotracheal tube [29]. Dysphagia is commonly diagnosed by a swallow evaluation at the bedside, a flexible fiberoptic endoscopy evaluation of swallowing, or a videofluoroscopic swallow study [30]. Dummy variables were created, and the category with the hypothesized lowest incidence was chosen as the reference category. The meta-regression was performed with a Poisson regression with a random intercept, which corresponds to a random effects meta-regression. Details on this method can be found here [31,32]. Statistical heterogeneity was evaluated using tau 2 and the $\mathrm{I}^{2}$ statistic. Tau 2 is between study variance of the incidence rates, and I2 describes the proportion of variation in incidence estimates that is due to genuine variation rather than sampling error. Values for $\mathrm{I}^{2}$ of $50 \%$ or greater were considered to show substantial heterogeneity $[33,34]$. Analyses were performed with Stata, version 17 and $R(R$ Foundation for Statistical Computing, Vienna, Austria) and the packages meta [35] and metafor [36].

\section{Results}

\subsection{Studies Identified}

Literature searches identified 719 records, including duplicates. Figure 1 displays the flow of the inclusion of records. After exclusion through comparisons of titles and abstracts against inclusion criteria, 97 records were identified for detailed examination. In total, 71 records were excluded (Supplementary File S4) with the reasons listed in Figure 1. The main reason was that in 54 studies the wrong patient population was examined (Figure 1). Mainly, data for the sub-analyses for the SCI population were missing and therefore the numbers for incidence of pneumonia could not be used for our analyses.

Finally, 24 records met inclusion criteria, and 19 studies could be included in the analyses for the incidence rates and incidence rate ratios. Of the 24 included studies, only 2 designed their study specifically to report on incidence of pneumonia [37,38]. The study sample sizes ranged from 14 to 18,693 (median $=90$ ), and the studies were published between 2001 and 2020 and carried out in Europe $(n=7)$, Asia $(n=4)$ and the U.S. $(n=13)$. Of these 24 studies, 12 studies were prospective. Table 1 describes the study characteristics.

\subsection{Risk of Bias}

Supplementary File S3 is a tabular display of the overall risk-of-bias assessment. Of the 24 included papers, all studies were rated as having a high risk of bias; therefore, we did not undertake a risk-of-bias sensitivity analysis.

\subsection{Incidence Rates per 100 Person-Days and Incidence-Rate Ratios}

Meta-regression of 19 studies reporting on 34 study samples was conducted. Because Raab et al. and Smith et al. did not report cases per time units, both studies were excluded from the meta-regression. The study from McKinley et al. from 2002 and two studies from Shem et al. from 2011 and 2012 were also excluded because the use of patients in different studies is quite likely. Only the latest studies were included in the analyses to ensure that each patient is only included once in our analyses.

Figure 2 shows the incidence rates for each study and pooled for each subgroup. The incidence rates ranged from 0.06 to 3.98 per 100 person-days for the acute setting, from 0.27 to 7.21 per 100 person-days for the ICU setting, from 0 to 1.84 per 100 person-days for the rehabilitation setting, and from 0.03 to 0.96 for the post-rehabilitation setting. Figure 2 also shows that the heterogeneity remains high, even when subgroups are built with the combination of setting, level of injury, ventilation, tracheostomy, and dysphagia (high I2 in most subgroups). 
Table 1. Characteristics of 24 included studies with 34 subgroups.

\begin{tabular}{|c|c|c|c|c|c|c|c|c|c|c|}
\hline Citation & $\begin{array}{c}\text { Year of } \\
\text { Publication }\end{array}$ & Country & Type of Study & $\begin{array}{l}\text { Sample } \\
\text { Size }(n)\end{array}$ & Setting & $\begin{array}{l}\text { Mean Age } \\
\text { ( } \pm \text { SD) }\end{array}$ & $\begin{array}{c}\text { Sex } \\
\text { Male(\%) }\end{array}$ & $\begin{array}{c}\text { SCI } \\
\text { Classification } \\
\text { Using AIS } \\
\underset{(\%)}{(\%)}\end{array}$ & $\begin{array}{l}\text { SCI Level of } \\
\text { Injury (\%) }\end{array}$ & $\begin{array}{c}\text { Mechanical } \\
\text { Ventilator } \\
\text { Depen-Dency } \\
(\%)\end{array}$ \\
\hline $\begin{array}{l}\text { Choi et al. [39] } \\
\text { Early Tracheostomy }\end{array}$ & 2013 & Korea & retro-spective & 10 & ICU & $54 \pm 14$ & 90 & $\begin{array}{l}\text { A } 20 \\
\text { B } 20 \\
\text { C } 60 \\
\text { D } 0 \\
\end{array}$ & Tetra 100 & 70 \\
\hline $\begin{array}{l}\text { Choi et al. [39] } \\
\text { Late Tracheostomy }\end{array}$ & 2013 & Korea & retrospective & 11 & ICU & $46 \pm 17$ & 91 & $\begin{array}{l}\text { A } 55 \\
\text { B } 9 \\
\text { C } 27 \\
\text { D } 9\end{array}$ & Tetra 100 & 100 \\
\hline $\begin{array}{c}\text { Citak et al. [40] } \\
\text { Heterotopic Ossification }\end{array}$ & 2012 & Germany & pro-spective & 132 & Mixed & $43 \pm$ N.M. & 84 & $\begin{array}{c}\text { A } 83 \\
\text { B,C,D } 17\end{array}$ & $\begin{array}{l}\text { Tetra } 55 \\
\text { Para } 45\end{array}$ & N.M. \\
\hline $\begin{array}{c}\text { Citak et al. [40] } \\
\text { No Heterotopic Ossification }\end{array}$ & 2012 & Germany & pro-spective & 132 & Mixed & $49 \pm$ N.M. & 77 & $\begin{array}{c}\text { A } 46 \\
\text { B,C,D } 54\end{array}$ & $\begin{array}{l}\text { Tetra } 49 \\
\text { Para } 51\end{array}$ & N.M. \\
\hline $\begin{array}{l}\text { Fenton et al. [41] } \\
\text { High Tidal }\end{array}$ & 2016 & USA & pro-spective & 16 & ICU & $39 \pm 13$ & 88 & $\mathrm{~A}, \mathrm{~B}, \mathrm{C} 100$ & Tetra 100 & 100 \\
\hline $\begin{array}{l}\text { Fenton et al. [41] } \\
\text { Low Tidal }\end{array}$ & 2016 & USA & pro-spective & 17 & ICU & $27 \pm 7$ & 65 & $\mathrm{~A}, \mathrm{~B}, \mathrm{C} 100$ & Tetra 100 & 100 \\
\hline Fussenich et al. [42] & 2018 & Germany & retro-spective & 165 & ICU & $57 \pm 17$ & 79 & $\begin{array}{l}\text { A } 46 \\
\text { B } 12 \\
\text { C } 32 \\
\text { D } 11\end{array}$ & $\begin{array}{l}\text { Tetra } 82 \\
\text { Para } 19\end{array}$ & 100 \\
\hline Garcia-Leoni et al. [37] & 2010 & Spain & pro-spective & 100 & $\begin{array}{c}\text { LT- } \\
\text { Ventilated }\end{array}$ & $49 \pm 17$ & 75 & N.M. & $\begin{array}{c}\text { Tetra } 58 \\
\text { (missing data } \\
\text { N.M.) }\end{array}$ & 100 \\
\hline $\begin{array}{l}\text { Hatton et al. [43] } \\
\text { HighTidal Volume }\end{array}$ & 2020 & USA & retro-spective & 22 & ICU & $\begin{array}{c}40 \\
(27-51)\end{array}$ & 77 & $\begin{array}{c}\text { A } 73 \\
\text { B,C,D } 27\end{array}$ & Tetra 100 & 100 \\
\hline $\begin{array}{c}\text { Hatton et al. [43] } \\
\text { Standard Tidal Voluma }\end{array}$ & 2020 & USA & retro-spective & 159 & ICU & $\begin{array}{c}53 \\
(35-70)\end{array}$ & 79 & $\begin{array}{c}\text { A } 38 \\
\text { B,C,D } 62\end{array}$ & Tetra 100 & 100 \\
\hline
\end{tabular}


Table 1. Cont.

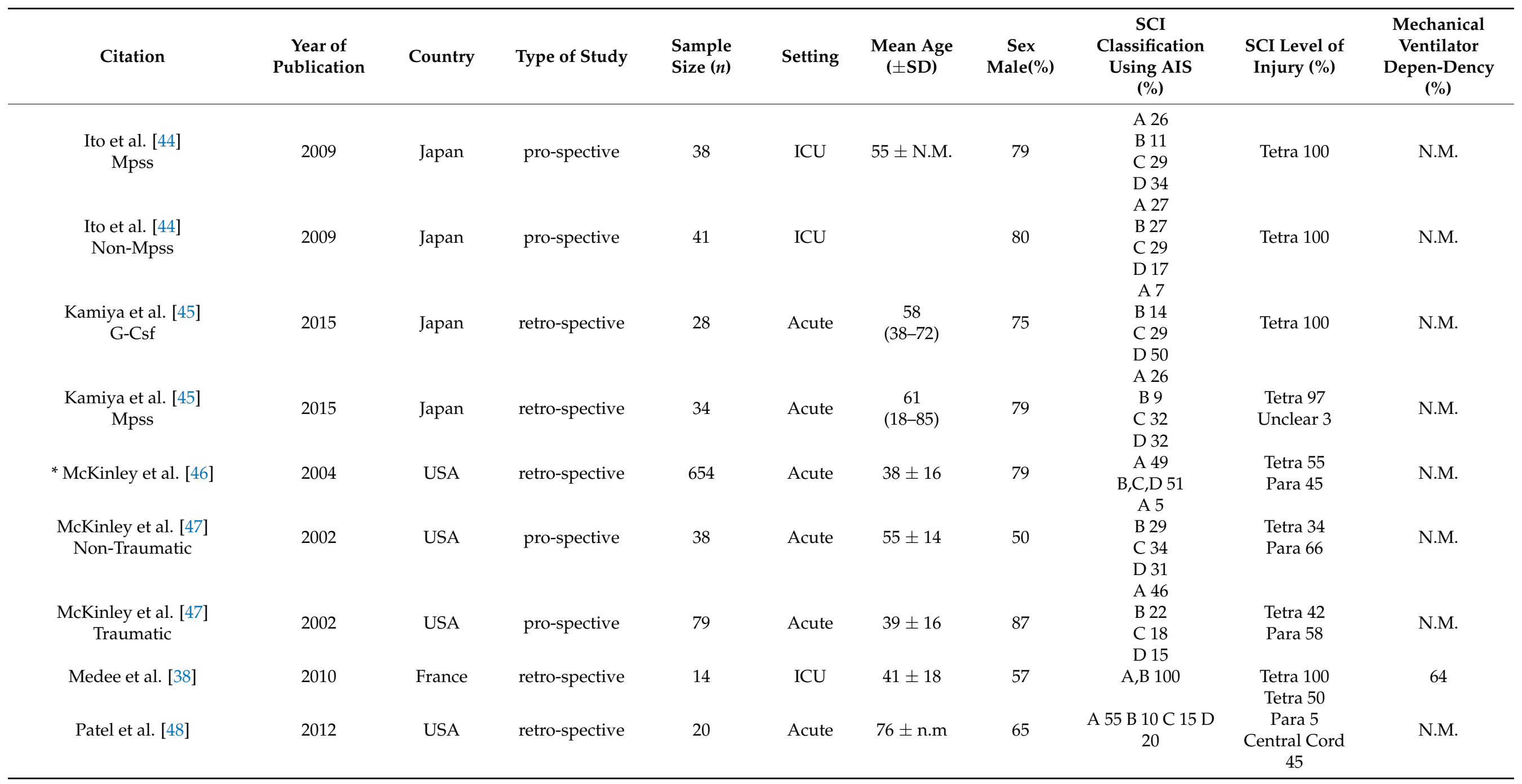


Table 1. Cont.

\begin{tabular}{|c|c|c|c|c|c|c|c|c|c|c|}
\hline Citation & $\begin{array}{c}\text { Year of } \\
\text { Publication }\end{array}$ & Country & Type of Study & $\begin{array}{l}\text { Sample } \\
\text { Size }(n)\end{array}$ & Setting & $\begin{array}{l}\text { Mean Age } \\
\quad( \pm \text { SD) }\end{array}$ & $\begin{array}{c}\text { Sex } \\
\text { Male(\%) }\end{array}$ & $\begin{array}{c}\text { SCI } \\
\text { Classification } \\
\text { Using AIS } \\
(\%)\end{array}$ & $\begin{array}{l}\text { SCI Level of } \\
\text { Injury (\%) }\end{array}$ & $\begin{array}{c}\text { Mechanical } \\
\text { Ventilator } \\
\text { Depen-Dency } \\
(\%)\end{array}$ \\
\hline Raab et al. [49] & 2016 & Switzer-land & retro-spective & 307 & Mixed & $\begin{array}{l}53 \pm 15 \\
53 \pm 18\end{array}$ & 81 & $\begin{array}{l}\text { A } 58 \\
\text { B } 20 \\
\text { C } 13 \\
\text { D } 9\end{array}$ & N.M. & N.M. \\
\hline $\begin{array}{l}\text { Shem et al. [19] } \\
\text { No Dysphagia }\end{array}$ & 2011 & USA & pro-spective & 17 & Acute & $35 \pm 12$ & 71 & N.M. & Tetra 100 & 41 \\
\hline $\begin{array}{l}\text { Shem et al. [19] } \\
\text { Dysphagia }\end{array}$ & 2011 & USA & pro-spective & 12 & Acute & $49 \pm 21$ & 83 & N.M. & Tetra 100 & 67 \\
\hline $\begin{array}{l}\text { Shem et al. [20] } \\
\text { No Dysphagia }\end{array}$ & 2012 & USA & pro-spective & 24 & Acute & $36 \pm 13$ & 71 & A 54 B,C,D 46 & Tetra 100 & 46 \\
\hline $\begin{array}{l}\text { Shem et al. [20] } \\
\text { Dysphagia }\end{array}$ & 2012 & USA & pro-spective & 16 & Acute & $51 \pm 18$ & 88 & A 25 B,C,D 75 & Tetra 100 & 88 \\
\hline $\begin{array}{l}\text { Shem et al. [30] } \\
\text { No Dysphagia }\end{array}$ & 2019 & USA & pro-spective & 53 & Acute & $39 \pm 17$ & 79 & $\begin{array}{c}\text { A } 47 \\
\text { B,C,D } 53\end{array}$ & Tetra 100 & 40 \\
\hline $\begin{array}{l}\text { Shem et al. [30] } \\
\text { Dysphagia }\end{array}$ & 2019 & USA & pro-spective & 23 & Acute & $48 \pm 19$ & 91 & $\begin{array}{c}\text { A } 35 \\
\text { B,C,D } 65 \\
\text { A } 24\end{array}$ & $\begin{array}{c}\text { Tetra } 100 \\
\text { Tetra } 33\end{array}$ & 65 \\
\hline Smith et al. [50] & 2007 & USA & retro-spective & 18.693 & Mixed & $56 \pm 14$ & 98 & $\begin{array}{c}\text { B,C,D } 27 \\
\text { Unknown } 32\end{array}$ & & N.M. \\
\hline Stillman et al. [51] & 2017 & USA & pro-spective & 169 & $\begin{array}{l}\text { Post- } \\
\text { Rehab }\end{array}$ & $41 \pm 16$ & 79 & $\begin{array}{c}\text { A,B,C } 48 \\
\text { D } 50 \\
\text { Unknown } 2\end{array}$ & $\begin{array}{c}\text { Tetra } 23 \\
\text { Para } 65 \\
\text { Unknown } 2\end{array}$ & N.M. \\
\hline Street et al. [52] & 2015 & Canada & pro-spective & 171 & $\begin{array}{l}\text { Post- } \\
\text { Rehab }\end{array}$ & $47 \pm 20$ & 81 & N.M. & N.M. & N.M. \\
\hline Unsal-Delialioglu et al. [53] & 2010 & Turkey & retro-spective & 392 & Acute & $37 \pm 14$ & 76 & $\begin{array}{l}\text { A } 52 \\
\text { B } 11 \\
\text { C } 19 \\
\text { D } 18\end{array}$ & N.M. & N.M. \\
\hline $\begin{array}{l}\text { \# Wahman et al. [54] } \\
\text { Para }\end{array}$ & 2019 & Sweden & pro-spective & 45 & Acute & $55 \pm 17$ & 60 & $\begin{array}{c}\text { A } 29 \\
\text { B,C,D } 71\end{array}$ & $\begin{array}{l}\text { Tetra } 71 \\
\text { Para } 29\end{array}$ & $\begin{array}{c}\text { Yes } \\
\text { (number N.M.) }\end{array}$ \\
\hline $\begin{array}{c}\text { Younan et al. [55] } \\
\text { Latent Coagulopathy }\end{array}$ & 2016 & USA & retro-spective & 73 & ICU & $39 \pm 17$ & 82 & N.M. & $\begin{array}{l}{ }^{\circ} \text { Tetra N.M. } \\
\text { Para N.M. }\end{array}$ & 100 \\
\hline
\end{tabular}


Table 1. Cont.

\begin{tabular}{|c|c|c|c|c|c|c|c|c|c|c|}
\hline Citation & $\begin{array}{c}\text { Year of } \\
\text { Publication }\end{array}$ & Country & Type of Study & $\begin{array}{l}\text { Sample } \\
\text { Size }(n)\end{array}$ & Setting & $\begin{array}{l}\text { Mean Age } \\
\quad( \pm \text { SD) }\end{array}$ & $\begin{array}{c}\text { Sex } \\
\text { Male(\%) }\end{array}$ & $\begin{array}{c}\text { SCI } \\
\text { Classification } \\
\text { Using AIS } \\
(\%)\end{array}$ & $\begin{array}{l}\text { SCI Level of } \\
\text { Injury (\%) }\end{array}$ & $\begin{array}{c}\text { Mechanical } \\
\text { Ventilator } \\
\text { Depen-Dency } \\
(\%)\end{array}$ \\
\hline $\begin{array}{c}\text { Younan et al. [55] } \\
\text { Admission Coagulopathy }\end{array}$ & 2016 & USA & retro-spective & 88 & ICU & $39 \pm 20$ & 81 & N.M. & $\begin{array}{l}{ }^{\circ} \text { Tetra N.M. } \\
\text { Para N.M. } \\
\circ \text { Tetra }\end{array}$ & 100 \\
\hline $\begin{array}{l}\text { Younan et al. [55] } \\
\text { No Coagulopathy }\end{array}$ & 2016 & USA & retro-spective & 126 & Rehab & $44 \pm 16$ & 82 & N.M. & $\begin{array}{l}\text { N.M.Para } \\
\text { N.M. }\end{array}$ & 100 \\
\hline $\begin{array}{l}\text { Yu et al. [56] } \\
\text { Unsuccessful Weaning }\end{array}$ & 2015 & Taiwan & retro-spective & 19 & ICU & $64 \pm 17$ & 84 & $\begin{array}{c}\infty \text { A } 34 \text { B } 10 \text { C } \\
10 \text { D } 4 \\
\text { Unknown } 43\end{array}$ & Tetra 100 & 100 \\
\hline $\begin{array}{l}\text { Vitaz et al. [57] } \\
\text { No Pathway }\end{array}$ & 2001 & USA & retro-spective & 22 & ICU & $34 \pm 10$ & N.M. & N.M. & $\begin{array}{l}\text { Tetra } 86 \\
\text { Para } 14\end{array}$ & $\begin{array}{c}\text { Yes } \\
\text { (number N.M.) }\end{array}$ \\
\hline $\begin{array}{l}\text { Vitaz et al. [57] } \\
\text { Pathway }\end{array}$ & 2001 & USA & pro-spective & 36 & ICU & $33 \pm 15$ & N.M. & N.M. & $\begin{array}{l}\text { Tetra } 89 \\
\text { Para } 11\end{array}$ & $\begin{array}{c}\text { Yes } \\
\text { (number N.M.) }\end{array}$ \\
\hline
\end{tabular}




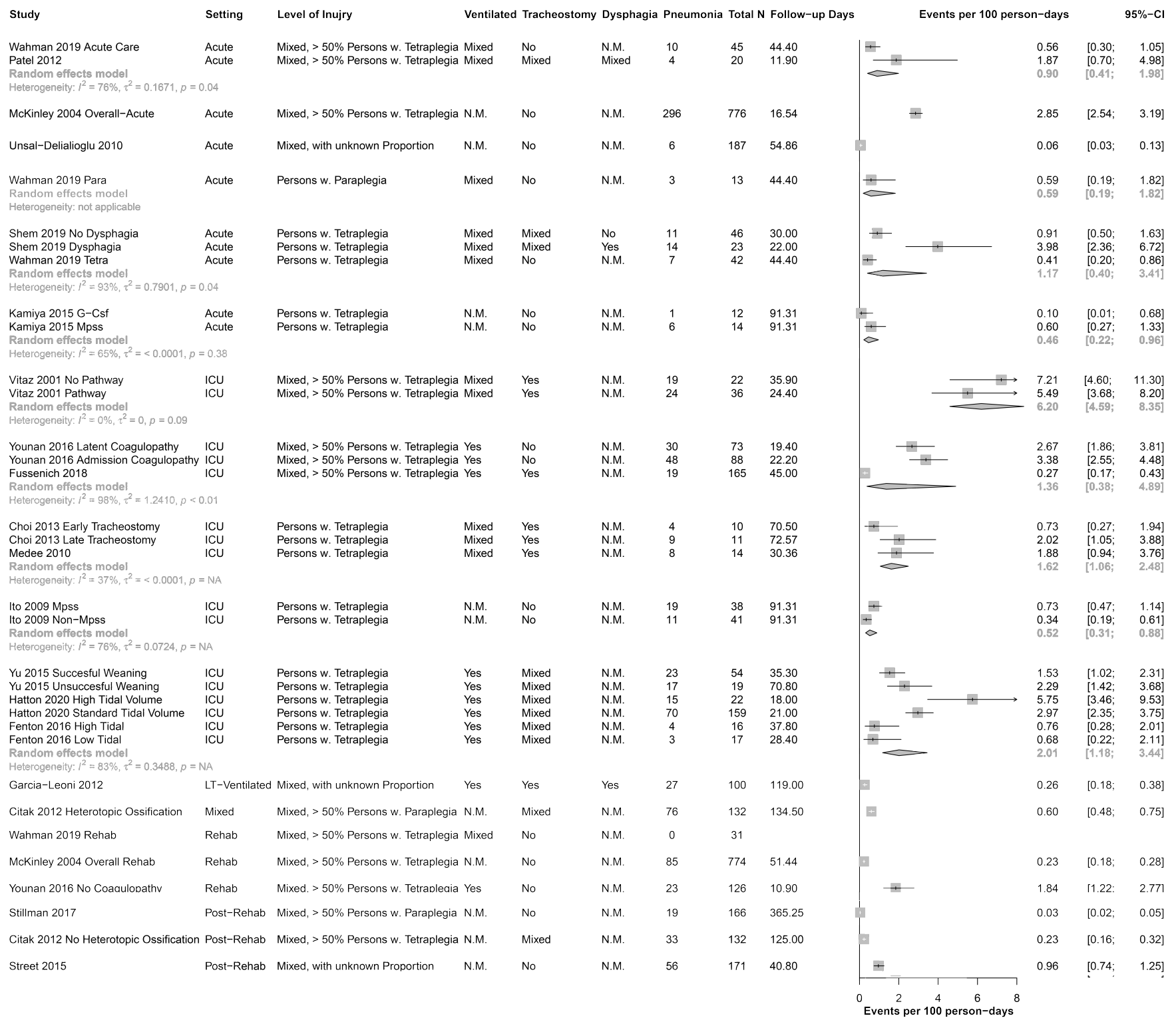

Figure 2. Forest Plot of all included study samples, without pooled results. $\mathrm{CI}=$ confidence interval; Fup, Follow up; G-Csf, granulocyte colonystimulating factor; ICU, Intensive Care Unit; LT-Ventilated, long-term ventilated; MPSS, high-dose methylprednisolone sodium succinate; n.m., not mentioned; Para, paraplegia; Rehab, rehabilitation; Tetra, tetraplegia; Ventilation, mechanical ventilation.

Table 2 shows the univariable and multivariable incidence rate ratios. For the setting, the incidence-rate ratio was 8.20 (95\% CI 2.21 to 30.39) for the ICU compared to the postrehabilitation setting. The incidence-rate ratios for the other settings were not statistically significant. The only other significant incidence-rate ratios were for the ventilated and mixed versus the studies where no information was given for the mechanical ventilation.

In the multivariable meta-regression (adjusted for setting, level of injury, ventilation, and tracheostomy), the incidence rate was only significant for the mixed setting versus the post-rehabilitation setting (IRR 15.76, 95\% Ci 1.31 to 189.45), and the studies with a mix of ventilated and non-ventilated patients versus those with no information on ventilation (IRR 5.07, 95\% CI 1.58 to 16.25). 
Table 2. Univariable and multivariable Meta-Regression including Setting, Level of Injury, Ventilation, Tracheostomy, and Dysphagia.

\begin{tabular}{|c|c|c|c|c|c|c|}
\hline \multirow[b]{2}{*}{ Variable } & \multicolumn{3}{|c|}{ Univariable Meta-Regression } & \multicolumn{3}{|c|}{ Multivariable Meta-Regression } \\
\hline & $\begin{array}{l}\text { Incidence } \\
\text { Rate Ratio }\end{array}$ & $95 \%$ CI & $p$-Value & $\begin{array}{l}\text { Incidence } \\
\text { Rate Ratio }\end{array}$ & $95 \% \mathrm{CI}$ & $p$-Value \\
\hline \multicolumn{7}{|l|}{ Setting } \\
\hline Post-Rehab (Reference) & 1.00 & & & 1.00 & & \\
\hline Acute & 3.25 & 0.81 to 12.97 & 0.095 & 0.65 & 0.13 to 3.35 & 0.605 \\
\hline ICU & 8.20 & 2.21 to 30.39 & 0.002 & 2.27 & 0.32 to 15.93 & 0.410 \\
\hline Long-Term Ventilation & 1.33 & 0.12 to 14.6 & 0.817 & 0.97 & 0.05 to 17.64 & 0.983 \\
\hline Mixed & 3.08 & 0.28 to 33.3 & 0.355 & 15.76 & 1.31 to 189.45 & 0.030 \\
\hline Rehab & 3.23 & 0.49 to 21.41 & 0.224 & 0.75 & 0.1 to 5.9 & 0.785 \\
\hline \multicolumn{7}{|l|}{ Level of Injury } \\
\hline Persons w. Paraplegia (Reference) & 1.00 & & & & & \\
\hline Mixed, $>50 \%$ Persons w. Paraplegia & 0.28 & 0.02 to 4.62 & 0.371 & 0.20 & 0.01 to 0.01 & 0.296 \\
\hline Mixed, $>50 \%$ Persons w. Tetraplegia & 2.54 & 0.22 to 30.11 & 0.459 & 3.64 & 0.41 to 0.41 & 0.244 \\
\hline Persons w. Tetraplegia & 2.03 & 0.18 to 23.46 & 0.571 & 1.93 & 0.21 to 0.21 & 0.562 \\
\hline Mixed, with unknown Proportion & 0.49 & 0.03 to 7.17 & 0.601 & 1.99 & 0.16 to 0.16 & 0.596 \\
\hline \multicolumn{7}{|l|}{ Ventilation } \\
\hline Not mentioned (Reference) & 1.00 & & & & & \\
\hline Mixed & 4.70 & 1.89 to 11.72 & 0.001 & 5.07 & 1.58 to 16.25 & 0.006 \\
\hline Ventilated & 4.34 & 1.76 to 10.71 & 0.001 & 2.03 & 0.61 to 6.73 & 0.247 \\
\hline \multicolumn{7}{|l|}{ Tracheostomy } \\
\hline No (Reference) & 1.00 & & & & & \\
\hline Mixed & 2.55 & 0.99 to 6.57 & 0.053 & 1.17 & 0.42 to 3.21 & 0.763 \\
\hline Yes & 2.52 & 0.85 to 7.48 & 0.096 & 0.41 & 0.1 to 1.69 & 0.217 \\
\hline \multicolumn{7}{|l|}{ Dysphagia } \\
\hline No (Reference) & 1.00 & & & * & & \\
\hline Not mentioned & 0.95 & 0.07 to 12.18 & 0.968 & & & \\
\hline Mixed & 1.93 & 0.05 to 72.32 & 0.722 & & & \\
\hline Yes & 1.13 & 0.05 to 24.19 & 0.938 & & & \\
\hline $\begin{array}{l}* \text { Too fe } \\
\text { not inc } \\
\text { inciden } \\
\text { other v }\end{array}$ & $\begin{array}{l}\text { dies with it } \\
\text { dysphagia it } \\
\text { r } 100 \text { days is } \\
\text { les). }\end{array}$ & $\begin{array}{l}\text { nation on dys } \\
\text { multivariable } \\
\text { er compared }\end{array}$ & $\begin{array}{l}\text { gia (only t } \\
\text { del. Incid } \\
\text { he referenc }\end{array}$ & $\begin{array}{l}\text { studies report } \\
\text { Rate Ratio: } \\
\text { tegory, (in mu }\end{array}$ & $\begin{array}{l}\text { on dysphagia), } \\
\text { coefficient): hov } \\
\text { ariable analysis: }\end{array}$ & $\begin{array}{l}\text { efore, we c } \\
\text { any times } t \\
\text { trolled for }\end{array}$ \\
\hline
\end{tabular}

\subsection{Sensitivity Analyses}

The sensitivity analyses (Supplementary File S5) with the two alternative calculations of the time under risk did not produce results that would change the conclusion.

\section{Discussion}

This systematic review and meta-regression of 24 studies analyzed the incidence of pneumonia in SCI. All studies had a high risk of bias with high heterogeneity, and this was evident even in the subgroup analyses. While pooled estimates of incidence would be useful to indicate the public health burden of pneumonia in SCI, we have only low confidence in our pooled estimates of the incidence, which ranged from 0.03 to 7.21 patients with pneumonia per 100 days. This low confidence results mainly because of (i) the design of the studies, which were not specifically designed to analyze the incidence of pneumonia, (ii) the reporting of the follow-up time (time at risk), (iii) the small sample sizes, (iv) the non-standardized reporting of the outcome variables and the risk factors (i.e., setting, level of injury, mechanical ventilation, tracheostomy, dysphagia), (v) not all studies had a longitudinal design, and (vi) the high risk of bias.

Despite this, our results suggest that shortly after the onset of a SCI, when the patient is in an ICU, the incidence of pneumonia was almost five times as high as in the time after subsequent discharge from the rehabilitation setting. Given that most pneumonia occurs early after the SCI (Figure 2), we propose the need for a greater focus on regular screening 
of pulmonary and respiratory muscle function in the ICU and implementation of potential strategies to enhance pulmonary and respiratory muscle function (e.g., physiotherapy and respiratory muscle training).

\subsection{Overall Completeness of Evidence}

The overall completeness of evidence with 24 identified studies appears to be sufficient to address the incidence of pneumonia in SCI, taking into account the wide $95 \%$ confidence intervals. Most studies reported the incidence of pneumonia in SCI, and a minority reported the point prevalence or the period prevalence of pneumonia. We therefore decided to focus on incidence estimates. The analyses of incidence rates had the limitation that the time under risk was not reported. For a correct follow-up time, the follow-up days should only be counted up to the diagnosis of a pneumonia, and most studies reported the overall follow-up time, i.e., including the days where a patient was already diagnosed with a pneumonia. Therefore, we had to estimate the follow-up time by adjusting the days for patients with pneumonia (i.e., we took only half of these days for cases).

\subsection{Covartiates}

\subsubsection{Setting}

The clinical setting influences the incidence of pneumonia. Rates are considerably higher among patients hospitalized in ICUs compared with those in hospital wards $[29,58]$. These findings are confirmed in this systematic review; the incidence of pneumonia in SCI is also highest in ICU and decreases with time post injury (Figure 2). The clinical setting varied between the studies we examined. For example, in some studies pneumonia was identified at ICU during the acute phase of SCI, and in others pneumonia was identified in the rehabilitation phase or later in the outpatient setting.

\subsubsection{Level of Injury}

We investigated the incidence of pneumonia according to the level of injury. We divided the level of injury into tetraplegia and paraplegia because the degree of respiratory impairment depends on the level of injury, with higher levels of injury causing greater impairment $[15,59]$. Generally, the incidence of pneumonia is higher in high-level tetraplegia in comparison to low-level tetraplegia and paraplegia [6]. However, one study in this review directly compared patients with tetraplegia and paraplegia with comparable personal/baseline characteristics [54] and could not confirm this statement.

\subsubsection{Mechanical Ventilation}

For patients receiving mechanical ventilation, the risk of pneumonia is increased 3- to 10 -fold $[29,58,60]$. The incidence of ventilator-associated pneumonia ranged from $8 \%$ to $28 \%[58,61]$. Ventilator-associated pneumonia is defined as pneumonia occurring $>48 \mathrm{~h}$ after endotracheal intubation [62]. Some use the term hospital-acquired pneumonia to denote any pneumonia developing in the hospital (including ventilator-associated pneumonia) and others exclude ventilator-associated pneumonia from the hospital-acquired pneumonia designation [62]. Therefore, the comparability of the literature is complicated by inconsistent usage of the terms. Four of the studies in this review used the term "ventilator-associated pneumonia" [37,42,43,55] and one study used the term "hospital-acquired infection" [63]. The difference between successful or unsuccessful weaning from mechanical ventilation showed differences in the incidences of pneumonia, but this relies on only one study and hence no conclusion can be drawn. From all pneumonia events in hospital, about $60 \%$ occur in non-ventilated patients with SCI [64]. The incidence of hospital-acquired pneumonia is low $(1.6 \%)$ in the non-ventilated general population [65]. These $1.6 \%$ correspond to about $22 \%$ of all hospital-acquired infections. 


\subsubsection{Tracheostomy}

Tracheostomy seems likely to influence the incidence of pneumonia, but this relies only on one single study [39]. In this study, no statistical significance for the timing of tracheostomy and pneumonia was given. Other studies report that the rates of pneumonia in SCI cannot be reduced by the timing of tracheostomy [66,67]. However, the timing of the tracheostomy within 7 days of entry to ICU is associated with a shorter duration of mechanical ventilation and shorter length of ICU stay [66-68]. A review of patients with trauma in ICU summarized the impact of timing of tracheostomy on pneumonia, and it reported that some studies found a reduction in pneumonia but some did not [69].

\subsubsection{Dysphagia}

Dysphagia seems to be an important variable linked to the incidence of pneumonia, but only a few studies provided data that could be used. The most common cause of death in patients with dysphagia due to neurological disorders is aspiration pneumonia [70,71]. This is defined as an infection caused by the inhalation of oropharyngeal secretions that are colonized by pathogenic bacteria [72]. Generally, 5\% to 15\% of cases with communityacquired pneumonia are aspiration pneumonia [72,73]. The included studies in this review did not formally consider aspiration pneumonia.

\subsubsection{General Aspects}

Due to the different compositions of setting, level of injury, mechanical ventilation, tracheostomy, and dysphagia in our sub-analyses, a direct comparison with the general population is difficult.

Generally, to reduce pneumonia incidence, a rapid identification of infected patients and appropriate antimicrobial or other treatment is required [58]. Unfortunately, qualitative influence on incidence such as time since injury, type of bacterial pneumonia or smoking could not be included due to missing details in the studies. In the future, it would be valuable to have more thorough recording of study characteristics with a clear definition of pneumonia type, setting, and description of ventilation or dysphagia to facilitate future meta-analyses.

\subsection{Strengths and Limitations}

Our search strategy was planned to comprise extensive literature searches of several major electronic databases as well as contact with experts in the field. Despite these searches, we might miss eligible studies, in particular if they are not published in indexed peer-reviewed journals. This might lead to a reporting bias [74]. Our literature search revealed three papers that were unable to be translated, and this constitutes a potential selection bias. Generally, the included studies were conducted in high-income countries, and therefore, the incidence of pneumonia after SCI in low-income countries could not be reflected in this systematic review. Due to the specific patient group and the strictly defined research question, we did not expect a large number of studies for inclusion. The number of included studies in each single sub-analysis was low (Figure 2). We are aware that many of the included studies were interventional studies with multiple inclusion and exclusion criteria and therefore increased potential risk for pneumonia that could bias our outcomes as well, but in this way all types of pneumonia were included to get an overview of the full picture in SCI. For the covariate setting, the acute phase is not a standardized term and therefore the time period was defined differently in the included studies or was not defined at all; this can lead to a mixture of different times post injury. Even if we had already tried to specify potential sources of clinical diversity by defining strict inclusion criteria in the protocol, we still had high heterogeneity according to the statistical I2 test (Figure 2). Most studies reported cumulative incidences, i.e., the number of events divided by the number of participants. Incidence rates (cases with pneumonia divided by the observed person-time) would be a better statistic, but few studies reported the time the persons were at risk. A further important source of clinical heterogeneity 
can be the insufficient definition of diagnostic criteria for pneumonia in a number of the included studies (Supplementary File S3). Usually, with high diversity in a systematic review, conclusions need to be interpreted with caution or seen as hypotheses. Finally, we relied on the quality and quantity of available published information. Nonetheless, to our knowledge, this is the first attempt at a systematic review of the incidence of pneumonia in SCI.

\section{Conclusions}

The main finding of this systematic review and meta-regression is that we found large heterogeneity in the reporting of the incidence of pneumonia, and we therefore should be cautious with interpreting the results. Our overall incidence ranged from 0.03 to 7.21 patients with pneumonia per 100 days, with higher incidence in the acute and ICU setting than later after injury. Large longitudinal studies with a standardized reporting of risk factors, pneumonia, and detailed time under observation are needed. Nevertheless, this review showed that pneumonia is still a clinically relevant complication, and special attention to pneumonia prevention should focus on the ICU setting and patients with complete tetraplegia. We need to focus more on regular screening of pulmonary and respiratory muscle function in the ICU and doing what we can to enhance function (e.g., by respiratory muscle training).

Supplementary Materials: The following are available online at https: / www.mdpi.com/article/ 10.3390/jcm11010211/s1, Supplementary File S1: Search Strategy, Supplementary File S2: Risk-ofBias-tool, Supplementary File S3: Risk-of-Bias assessment summary, Supplementary File S4: List of excluded full texts, Supplementary File S5: Sensitivity analyses with two alternative calculations of the time under risk.

Author Contributions: Conceptualization, A.M.R., G.M. and R.H.; methodology, A.M.R. and R.H.; software, R.H.; validation, A.M.R., R.H. and M.Z.; formal analysis, A.M.R. and S.E.; data curation, R.H., M.Z.; writing—original draft preparation, A.M.R.; writing-review and editing, G.M., S.E., S.C.G., M.Z., M.T.E.H., R.H.; visualization, R.H.; supervision, M.T.E.H.; project administration, A.M.R.; All authors have read and agreed to the published version of the manuscript.

Funding: This research received no external funding.

Institutional Review Board Statement: Not applicable.

Informed Consent Statement: Not applicable.

Data Availability Statement: Detailed information on study data and analysis are available upon request from the corresponding author.

Acknowledgments: We thank the librarian Hildegard Oswald for her very helpful explanations regarding databases and for the literature search.

Conflicts of Interest: The authors declare no conflict of interest.

\section{References}

1. Marsolais, E.B.; Boninger, M.L.; McCormick, P.C.; Love, L.; Mackelprang, R.W.; Dalsey, W.C. Respiratory management following spinal cord injury: A clinical practice guideline for health-care professionals. J. Spinal Cord Med. 2005, 28, $259-293$.

2. Wang, A.Y.; Jaeger, R.J.; Yarkony, G.M.; Turba, R.M. Cough in spinal cord injured patients: The relationship between motor level and peak expiratory flow. Spinal Cord 1997, 35, 299-302. [CrossRef] [PubMed]

3. Lanig, I.S.; Peterson, W.P. The respiratory system in spinal cord injury. Phys. Med. Rehabil. Clin. N. Am. 2000, 11, 29-43. [CrossRef]

4. Savic, G.; DeVivo, M.J.; Frankel, H.L.; Jamous, M.A.; Soni, B.M.; Charlifue, S. Causes of death after traumatic spinal cord injury-a 70-year British study. Spinal Cord 2017, 55, 891-897. [CrossRef] [PubMed]

5. Jackson, A.B.; Groomes, T.E. Incidence of respiratory complications following spinal cord injury. Arch. Phys. Med. Rehabil. 1994, 75, 270-275. [CrossRef]

6. Berlly, M.; Shem, K. Respiratory management during the first five days after spinal cord injury. J. Spinal Cord Med. 2007, 30, 309-318. [CrossRef] [PubMed]

7. CDC. Causes of Pneumonia. Available online: https://www.cdc.gov/pneumonia/causes.html (accessed on 18 May 2021). 
8. Torres, A.; Blasi, F.; Peetermans, W.E.; Viegi, G.; Welte, T. The aetiology and antibiotic management of community-acquired pneumonia in adults in Europe: A literature review. Eur. J. Clin. Microbiol. Infect. Dis. 2014, 33, 1065-1079. [CrossRef] [PubMed]

9. Welte, T.; Torres, A.; Nathwani, D. Clinical and economic burden of community-acquired pneumonia among adults in Europe. Thorax 2012, 67, 71-79. [CrossRef] [PubMed]

10. Agostinello, J.; Battistuzzo, C.R.; Batchelor, P.E. Early clinical predictors of pneumonia in critically ill spinal cord injured individuals: A retrospective cohort study. Spinal Cord 2019, 57, 41-48. [CrossRef] [PubMed]

11. Osterthun, R.; Post, M.W.; van Asbeck, F.W.; van Leeuwen, C.M.; van Koppenhagen, C.F. Causes of death following spinal cord injury during inpatient rehabilitation and the first five years after discharge. A Dutch cohort study. Spinal Cord 2014, 52, 483-488. [CrossRef]

12. Ahoniemi, E.; Pohjolainen, T.; Kautiainen, H. Survival after spinal cord injury in Finland. J. Rehabil. Med. 2011, 43, 481-485. [CrossRef] [PubMed]

13. Lidal, I.B.; Snekkevik, H.; Aamodt, G.; Hjeltnes, N.; Biering-Sorensen, F.; Stanghelle, J.K. Mortality after spinal cord injury in Norway. J. Rehabil. Med. 2007, 39, 145-151. [CrossRef]

14. Weaver, F.M.; Smith, B.; Evans, C.T.; Kurichi, J.E.; Patel, N.; Kapur, V.K.; Burns, S.P. Outcomes of outpatient visits for acute respiratory illness in veterans with spinal cord injuries and disorders. Am. J. Phys. Med. Rehabil. 2006, 85, 718-726. [CrossRef]

15. Chen, C.F.; Lien, I.N.; Wu, M.C. Respiratory function in patients with spinal cord injuries: Effects of posture. Paraplegia 1990, 28, 81-86. [CrossRef] [PubMed]

16. Brown, R.; DiMarco, A.F.; Hoit, J.D.; Garshick, E. Respiratory dysfunction and management in spinal cord injury. Respir. Care 2006, 51, 853-868.

17. Emmi, V. [Guidelines for treatment of pneumonia in intensive care units]. Infez. Med. 2005, 7-17. Available online: https: / / pubmed.ncbi.nlm.nih.gov/16801748/ (accessed on 18 May 2021).

18. Hayashi, T.; Fujiwara, Y.; Sakai, H.; Kubota, K.; Kawano, O.; Mori, E.; Takao, T.; Masuda, M.; Morishita, Y.; Maeda, T. The time course of dysphagia following traumatic cervical spinal cord injury: A prospective cohort study. Spinal Cord 2020, 58, 53-57. [CrossRef]

19. Shem, K.; Castillo, K.; Wong, S.; Chang, J. Dysphagia in individuals with tetraplegia: Incidence and risk factors. J. Spinal Cord Med. 2011, 34, 85-92. [CrossRef]

20. Shem, K.; Castillo, K.; Wong, S.L.; Chang, J.; Kolakowsky-Hayner, S. Dysphagia and respiratory care in individuals with tetraplegia: Incidence, associated factors, and preventable complications. Top. Spinal Cord Inj. Rehabil. 2012, 18, 15-22. [CrossRef]

21. Martin, N.D.; Marks, J.A.; Donohue, J.; Giordano, C.; Cohen, M.J.; Weinstein, M.S. The mortality inflection point for age and acute cervical spinal cord injury. J. Trauma 2011, 71, 380-385; discussion 385-386. [CrossRef] [PubMed]

22. Munn, Z.; Moola, S.; Riitano, D.; Lisy, K. The development of a critical appraisal tool for use in systematic reviews addressing questions of prevalence. Int. J. Health Policy Manag. 2014, 3, 123-128. [CrossRef]

23. Moher, D.; Liberati, A.; Tetzlaff, J.; Altman, D.G. Preferred reporting items for systematic reviews and meta-analyses: The PRISMA statement. Int. J. Surg. 2010, 8, 336-341. [CrossRef] [PubMed]

24. Stroup, D.F.; Berlin, J.A.; Morton, S.C.; Olkin, I.; Williamson, G.D.; Rennie, D.; Moher, D.; Becker, B.J.; Sipe, T.A.; Thacker, S.B. Meta-analysis of observational studies in epidemiology: A proposal for reporting. Meta-analysis Of Observational Studies in Epidemiology (MOOSE) group. JAMA 2000, 283, 2008-2012. [CrossRef] [PubMed]

25. Biering-Sørensen, F.; DeVivo, M.; Charlifue, S.; Chen, Y.; New, P.; Noonan, V.; Post, M.; Vogel, L. International spinal cord injury core data set (version 2.0)—including standardization of reporting. Spinal Cord 2017, 55, 759-764. [CrossRef] [PubMed]

26. CDC. Lesson 3: Measures of Risk; Sectiion 2: Morbidity Frequency Measures. Available online: https://www.cdc.gov/csels/ dsepd/ss1978/lesson3/section2.html\#: \{\}:text=The\%20denominator\%20of\%20an \%20incidence,be $\% 20$ included $\% 20 \mathrm{in} \% 20$ the $\%$ 20numerator. (accessed on 18 May 2021).

27. Hoy, D.; Brooks, P.; Woolf, A.; Blyth, F.; March, L.; Bain, C.; Baker, P.; Smith, E.; Buchbinder, R. Assessing risk of bias in prevalence studies: Modification of an existing tool and evidence of interrater agreement. J. Clin. Epidemiol. 2012, 65, 934-939. [CrossRef] [PubMed]

28. Stijnen, T.; Hamza, T.H.; Ozdemir, P. Random effects meta-analysis of event outcome in the framework of the generalized linear mixed model with applications in sparse data. Stat. Med. 2010, 29, 3046-3067. [CrossRef]

29. Oliveira, J.; Zagalo, C.; Cavaco-Silva, P. Prevention of ventilator-associated pneumonia. Rev. Port. Pneumol. 2014, $20,152-161$. [CrossRef]

30. Shem, K.; Wong, J.; Dirlikov, B.; Castillo, K. Pharyngeal Dysphagia in Individuals With Cervical Spinal Cord Injury: A Prospective Observational Cohort Study. Top. Spinal Cord Inj. Rehabil. 2019, 25, 322-330. [CrossRef]

31. Spittal, M.J.; Pirkis, J.; Gurrin, L.C. Meta-analysis of incidence rate data in the presence of zero events. BMC Med. Res. Methodol. 2015, 15, 42. [CrossRef] [PubMed]

32. Kirkwood, B.R.; Sterne, J.A. Essential Medical Statistics; John Wiley \& Sons: Hoboken, NJ, USA, 2010.

33. Higgins, J.P.T.; Thompson, S.G.; Deeks, J.J.; Altman, D.G. Measuring inconsistency in meta-analyses. BMJ 2003, 327, 557-560. [CrossRef] [PubMed]

34. Higgins, J.P.; Thompson, S.G. Quantifying heterogeneity in a meta-analysis. Stat. Med. 2002, 21, 1539-1558. [CrossRef]

35. Balduzzi, S.; Rücker, G.; Schwarzer, G. How to perform a meta-analysis with R: A practical tutorial. Evid. Based Ment. Health 2019, 22, 153-160. [CrossRef] 
36. Viechtbauer, W. Conducting Meta-Analyses in R with the metafor Package. J. Stat. Softw. 2010, 36, 1-48. [CrossRef]

37. Garcia-Leoni, M.E.; Moreno, S.; Garcia-Garrote, F.; Cercenado, E. Ventilator-associated pneumonia in long-term ventilator-assisted individuals. Spinal Cord 2010, 48, 876-880. [CrossRef] [PubMed]

38. Medee, B.; Girard, R.; Loukili, A.; Loiseau, K.; Tell, L.; Rode, G. Lower respiratory events in seated tracheotomized tetraplegic patients. Eur. J. Phys. Rehabil. Med. 2010, 46, 37-42. [PubMed]

39. Choi, H.J.; Paeng, S.H.; Kim, S.T.; Lee, K.S.; Kim, M.S.; Jung, Y.T. The Effectiveness of Early Tracheostomy (within at least 10 Days) in Cervical Spinal Cord Injury Patients. J. Korean Neurosurg. Soc. 2013, 54, 220-224. [CrossRef] [PubMed]

40. Citak, M.; Suero, E.M.; Backhaus, M.; Aach, M.; Godry, H.; Meindl, R.; Schildhauer, T.A. Risk factors for heterotopic ossification in patients with spinal cord injury: A case-control study of 264 patients. Spine 2012, 37, 1953-1957. [CrossRef] [PubMed]

41. Fenton, J.J.; Warner, M.L.; Lammertse, D.; Charlifue, S.; Martinez, L.; Dannels-McClure, A.; Kreider, S.; Pretz, C. A comparison of high vs. standard tidal volumes in ventilator weaning for individuals with sub-acute spinal cord injuries: A site-specific randomized clinical trial. Spinal Cord 2016, 54, 234-238. [CrossRef]

42. Fussenich, W.; Hirschfeld Araujo, S.; Kowald, B.; Hosman, A.; Auerswald, M.; Thietje, R. Discontinuous ventilator weaning of patients with acute SCI. Spinal Cord 2018, 56, 461-468. [CrossRef]

43. Hatton, G.E.; Mollett, P.J.; Du, R.E.; Wei, S.; Korupolu, R.; Wade, C.E.; Adams, S.D.; Kao, L.S. High tidal volume ventilation is associated with ventilator-associated pneumonia in acute cervical spinal cord injury. J. Spinal Cord Med. 2020, 44, 775-781. [CrossRef] [PubMed]

44. Ito, Y.; Sugimoto, Y.; Tomioka, M.; Kai, N.; Tanaka, M. Does high dose methylprednisolone sodium succinate really improve neurological status in patient with acute cervical cord injury?: A prospective study about neurological recovery and early complications. Spine 2009, 34, 2121-2124. [CrossRef]

45. Kamiya, K.; Koda, M.; Furuya, T.; Kato, K.; Takahashi, H.; Sakuma, T.; Inada, T.; Ota, M.; Maki, S.; Okawa, A.; et al. Neuroprotective therapy with granulocyte colony-stimulating factor in acute spinal cord injury: A comparison with high-dose methylprednisolone as a historical control. Eur. Spine J. 2015, 24, 963-967. [CrossRef]

46. McKinley, W.; Meade, M.A.; Kirshblum, S.; Barnard, B. Outcomes of early surgical management versus late or no surgical intervention after acute spinal cord injury. Arch. Phys. Med. Rehabil. 2004, 85, 1818-1825. [CrossRef] [PubMed]

47. McKinley, W.O.; Tewksbury, M.A.; Godbout, C.J. Comparison of medical complications following nontraumatic and traumatic spinal cord injury. J. Spinal Cord Med. 2002, 25, 88-93. [CrossRef]

48. Patel, A.; Smith, H.E.; Radcliff, K.; Yadlapalli, N.; Vaccaro, A.R. Odontoid fractures with neurologic deficit have higher mortality and morbidity. Clin. Orthop. Relat. Res. 2012, 470, 1614-1620. [CrossRef]

49. Raab, A.M.; Krebs, J.; Perret, C.; Michel, F.; Hopman, M.T.; Mueller, G. Maximum Inspiratory Pressure is a Discriminator of Pneumonia in Individuals With Spinal-Cord Injury. Respir. Care 2016, 61, 1636-1643. [CrossRef]

50. Smith, B.M.; Evans, C.T.; Kurichi, J.E.; Weaver, F.M.; Patel, N.; Burns, S.P. Acute respiratory tract infection visits of veterans with spinal cord injuries and disorders: Rates, trends, and risk factors. J. Spinal Cord Med. 2007, 30, 355-361. [CrossRef]

51. Stillman, M.D.; Barber, J.; Burns, S.; Williams, S.; Hoffman, J.M. Complications of Spinal Cord Injury Over the First Year after Discharge from Inpatient Rehabilitation. Arch. Phys. Med. Rehabil. 2017, 98, 1800-1805. [CrossRef] [PubMed]

52. Street, J.T.; Noonan, V.K.; Cheung, A.; Fisher, C.G.; Dvorak, M.F. Incidence of acute care adverse events and long-term healthrelated quality of life in patients with TSCI. Spine J. 2015, 15, 923-932. [CrossRef]

53. Unsal-Delialioglu, S.; Kaya, K.; Sahin-Onat, S.; Kulakli, F.; Culha, C.; Ozel, S. Fever during rehabilitation in patients with traumatic spinal cord injury: Analysis of 392 cases from a national rehabilitation hospital in Turkey. J. Spinal Cord Med. 2010, 33, 243-248. [CrossRef]

54. Wahman, K.; Nilsson Wikmar, L.; Chlaidze, G.; Joseph, C. Secondary medical complications after traumatic spinal cord injury in Stockholm, Sweden: Towards developing prevention strategies. J. Rehabil. Med. 2019, 51, 513-517. [CrossRef]

55. Younan, D.; Lin, E.; Griffin, R.; Vanlandingham, S.; Waters, A.; Harrigan, M.; Pittet, J.F.; Kerby, J.D. Early Trauma-Induced Coagulopathy is Associated with Increased Ventilator-Associated Pneumonia in Spinal Cord Injury Patients. Shock 2016, 45, 502-505. [CrossRef]

56. Yu, W.K.; Ko, H.K.; Ho, L.I.; Wang, J.H.; Kou, Y.R. Synergistic impact of acute kidney injury and high level of cervical spinal cord injury on the weaning outcome of patients with acute traumatic cervical spinal cord injury. Injury 2015, 46, 1317-1323. [CrossRef]

57. Vitaz, T.W.; McIlvoy, L.; Raque, G.H.; Spain, D.A.; Shields, C.B. Development and implementation of a clinical pathway for spinal cord injuries. J. Spinal Disord. 2001, 14, 271-276. [CrossRef]

58. Chastre, J.; Fagon, J.Y. Ventilator-associated pneumonia. Am. J. Respir. Crit. Care Med. 2002, 165, 867-903. [CrossRef] [PubMed]

59. Berlowitz, D.J.; Tamplin, J. Respiratory muscle training for cervical spinal cord injury. Cochrane Database Syst. Rev. 2013, 7, CD008507. [CrossRef]

60. NNIS System. National Nosocomial Infections Surveillance (NNIS) System Report, Data Summary from January 1990-May 1999, issued June 1999. A report from the NNIS System. Am. J. Infect. Control 1999, 27, 520-532.

61. Bassetti, M.; Taramasso, L.; Giacobbe, D.R.; Pelosi, P. Management of ventilator-associated pneumonia: Epidemiology, diagnosis and antimicrobial therapy. Expert Rev. Anti-Infect. Ther. 2012, 10, 585-596. [CrossRef] [PubMed] 
62. Kalil, A.C.; Metersky, M.L.; Klompas, M.; Muscedere, J.; Sweeney, D.A.; Palmer, L.B.; Napolitano, L.M.; O’Grady, N.P.; Bartlett, J.G.; Carratalà, J.; et al. Management of Adults with Hospital-acquired and Ventilator-associated Pneumonia: 2016 Clinical Practice Guidelines by the Infectious Diseases Society of America and the American Thoracic Society. Clin. Infect. Dis. 2016, 63, e61-e111. [CrossRef] [PubMed]

63. Evans, C.T.; Lavela, S.L.; Weaver, F.M.; Priebe, M.; Sandford, P.; Niemiec, P.; Miskevics, S.; Parada, J.P. Epidemiology of hospitalacquired infections in veterans with spinal cord injury and disorder. Infect. Control Hosp. Epidemiol. 2008, 29, 234-242. [CrossRef] [PubMed]

64. Magill, S.S.; Edwards, J.R.; Bamberg, W.; Beldavs, Z.G.; Dumyati, G.; Kainer, M.A.; Lynfield, R.; Maloney, M.; McAllister-Hollod, L.; Nadle, J.; et al. Multistate point-prevalence survey of health care-associated infections. N. Engl. J. Med. 2014, 370, 1198-1208. [CrossRef]

65. Giuliano, K.K.; Baker, D.; Quinn, B. The epidemiology of nonventilator hospital-acquired pneumonia in the United States. Am. J. Infect. Control 2018, 46, 322-327. [CrossRef] [PubMed]

66. Galeiras Vazquez, R.; Rascado Sedes, P.; Mourelo Farina, M.; Montoto Marques, A.; Ferreiro Velasco, M.E. Respiratory management in the patient with spinal cord injury. BioMed Res. Int. 2013, 2013, 168757. [CrossRef] [PubMed]

67. Flanagan, C.D.; Childs, B.R.; Moore, T.A.; Vallier, H.A. Early Tracheostomy in Patients with Traumatic Cervical Spinal Cord Injury Appears Safe and May Improve Outcomes. Spine 2018, 43, 1110-1116. [CrossRef]

68. Ganuza, J.R.; Forcada, A.G.; Gambarrutta, C.; Buigues, E.D.D.L.L.; Gonzalez, V.E.M.; Fuentes, F.P.; Luciani, A.A. Effect of technique and timing of tracheostomy in patients with acute traumatic spinal cord injury undergoing mechanical ventilation. $J$. Spinal Cord Med. 2011, 34, 76-84. [CrossRef]

69. Arabi, Y.; Haddad, S.; Shirawi, N.; Al Shimemeri, A. Early tracheostomy in intensive care trauma patients improves resource utilization: A cohort study and literature review. Crit. Care 2004, 8, R347-R352. [CrossRef] [PubMed]

70. Ding, C.; Yang, Z.; Wang, J.; Liu, X.; Cao, Y.; Pan, Y.; Han, L.; Zhan, S. Prevalence of Pseudomonas aeruginosa and antimicrobialresistant Pseudomonas aeruginosa in patients with pneumonia in mainland China: A systematic review and meta-analysis. Int. J. Infect. Dis. 2016, 49, 119-128. [CrossRef]

71. Bath, P.M.; Lee, H.S.; Everton, L.F. Swallowing therapy for dysphagia in acute and subacute stroke. Cochrane Database Syst. Rev. 2018, 10, Cd000323. [CrossRef] [PubMed]

72. Marik, P.E. Aspiration pneumonitis and aspiration pneumonia. N. Engl. J. Med. 2001, 344, 665-671. [CrossRef] [PubMed]

73. Rodriguez, A.E.; Restrepo, M.I. New perspectives in aspiration community acquired Pneumonia. Expert Rev. Clin. Pharmacol. 2019, 12, 991-1002. [CrossRef] [PubMed]

74. The Cochrane Collaboration. Cochrane Handbook for Systematic Reviews of Interventions, Updated October 2019, 2nd ed.; WileyBlackwell: Hoboken, NJ, USA, 2019. 